
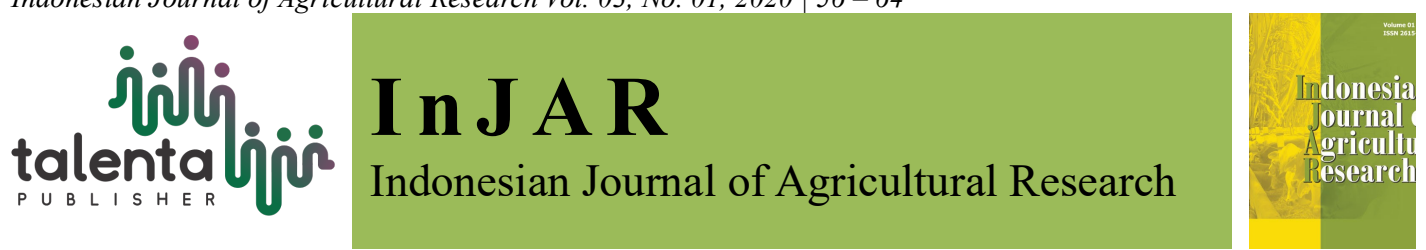

\title{
Impact of Entrepreneurial Characteristics and Access to Credit on Business Performance of Small Business (Case: Brown Sugar Processing in Agam District)
}

\author{
Nadia Firnalista, Nofialdi*, Zednita Azriani \\ Agricultural Economics Study Program, Faculty of Agriculture, Universitas Andalas, Indonesia
}

\begin{abstract}
Small businesses' performance needs to be improved because it plays an essential role in driving economic growth and development. This study focuses on examining the effect of entrepreneurial characteristics on small business performance. Data was collected through a survey by giving questionnaires to 100 small business entrepreneurs processing brown sugar. Structural Equation Model (SEM) was chosen to ensure the relationship between variables. Empirical findings indicate that entrepreneurial characteristics affect business performance directly and indirectly through credit access, entrepreneurial characteristics affect credit access, and credit access affects business performance. Business performance improvement of brown sugar entrepreneurs needs government assistance and building networks.
\end{abstract}

Key words: access credit, business performance, entrepreneurial characteristic, structural equation model (SEM)

Received 30 March 2020 | Revised 20 April 2020 | Accepted 30 June 2020

\section{Introduction}

A Small Business is an independently owned, operated, and funded business with a small number of employees less, which has a relatively small influence on the industry [1]. Small business has a significant impact on the Indonesia economy, looked by the amount of the business that reaches $91.67 \%$ in Indonesia in 2015. The development of small business companies is currently unable to increase business income, economic improvement, and social welfare because the support of the central and regional government policies is not yet maximum [2] [3] [4].

\footnotetext{
*Corresponding author at: Agribusiness Study Program, Universitas Andalas, Kampus Universitas Andalas Limau Manis, Padang, 25163, Indonesia

E-mail address: nofialdi@agr.unand.ac.id
} 
Business performance can be improved by characterizing entrepreneurship, one's character and motivation have a positive impact on business development [5] [6]. The entrepreneurial character and business performance influence the success of the small business. Entrepreneurial style influences business performance; better entrepreneurial character will have better business performance [7]. The character of the entrepreneur has a positive impact on the success of small businesses [8].

The problem of entrepreneurs in developing business is capital. Capital loans can increase entrepreneurial passion. Entrepreneurs who have character will use credit to improve operations and improve business performance. The availability of capital will make entrepreneurs better manage the company and better business performance.

The brown sugar processing business is one of the small business that has been developing in the Agam District for a long time. Brown sugar is the result of sugarcane processing, which is done traditionally or mechanically by processing farmers in rural areas. The brown sugar processing business still uses simple tools, carried out by entrepreneurs who are over 40 years old, have low education, have low entrepreneurial character, have not been managed with good management, so the business performance is low. Most brown sugar entrepreneurs have received capital loans, but business performance has not improved because the capital loans received are used to meet their daily needs. Improving business performance and entrepreneurship of brown sugar entrepreneurs in the Agam District needs to be done to use capital loans to develop their businesses.

The problem of entrepreneurs in developing business is capital. Capital loans can increase entrepreneurial passion. Entrepreneurs who have character will use credit to improve operations and improve business performance. The availability of capital will make entrepreneurs better manage the company and better business performance. This research is essential for the development of small business and entrepreneurship to improve the performance of brown sugar processing businesses in the Agam District. Entrepreneurial character and credit loans are needed to improve the business performance and income of small business entrepreneurs. Improved business performance will contribute to the increase in small business entrepreneur welfare and employment.

The formulation of the problem of this research is: "What is the effect of the character of the entrepreneur and loan credit on the performance of the brown sugar processing business in Agam District, West Sumatra?" This study aims to: (1) analyze the impact of entrepreneurial characteristics on the performance of brown sugar processing business, (2) analyze the impact of entrepreneurial characteristics on access to brown sugar processing credit, and (3) analyze the impact of access to credit on the performance of brown sugar processing business. 


\section{Research Methods}

Agam District is used as a research site because it has the largest area of people's sugar cane plantations in West Sumatra Province. The method used in this research is survey method. The population in this study is brown sugar processing entrepreneurs who can access credit from financial institutions. Samples were obtained by simple random sampling and cluster sampling methods. The number of samples is 100 . Variables are business performance, characteristics entrepreneurship (Long, and access to credit, with indicators as in Table 1.

Table 1. Research Variable and Indices

\begin{tabular}{llcl}
\hline No & Variable & & \multicolumn{1}{c}{ Indices } \\
\hline 1 & Business development (PU) & UU & Age \\
& & AM & Accumulation of Capital \\
& BI & Internal business process \\
& & TK & Workforce amount \\
& & SI & Instrumental \\
& SP & Creative \\
& SKB & Sociable \\
& SKK & Hard-work nature \\
& KD & Confidence in nature \\
& SPR & Calculated risk-taking nature \\
& SSK & Self-control nature \\
& Access to Credit (SK) & SIF & Innovative Nature \\
& & SK & Independent Nature \\
& & &
\end{tabular}

Data collection was done by interviews using a questionnaire, respondents' answers used a Likert scale with the lowest score of 1 , and the highest score of 5 [9]. To measure and construct structural models using the partial least squares structural equation modeling (PLS-SEM) using SmartPLS software.

This research has hypothesis to be analyzed, such as:

H1 : entrepreneurial characteristics significantly impact brown sugar processing business performance

H2 : entrepreneurial characteristics significantly impact access to credit

H3 : access to credit significantly impacts the performance of the brown sugar processing business 


\section{Results and Discussion}

The number of respondents consisted of $56 \%$ of women and $44 \%$ of men, mostly in the form of middle-aged adults, resilient in character, and had sufficient experience with having tried around 15-40 years and hereditary businesses. The education level is dominated by primary and secondary schools. Entrepreneurs' characters in the medium category are: instrumental, achievement, friendship, risk-taking, self-control, innovation and those in the high category are hard work, self-confidence.

Brown sugar entrepreneurs need capital to purchase mechanical presses, renovate factories, and replace production equipment. Most entrepreneurs get credit from 97\% of Agribusiness Microfinance Institutions (LKM-A) and others from banks.

\subsection{Measurement Model}

Based on the results of the convergent validity test on entrepreneurial characteristics, access to credit, and business performance, it is found that all indicators that have met the convergent validity criteria are loading factors $>0.5$, which can be seen in Figure 1 . The reliability value of the research variable is more than 0.7 and has met the composite reliability criteria.

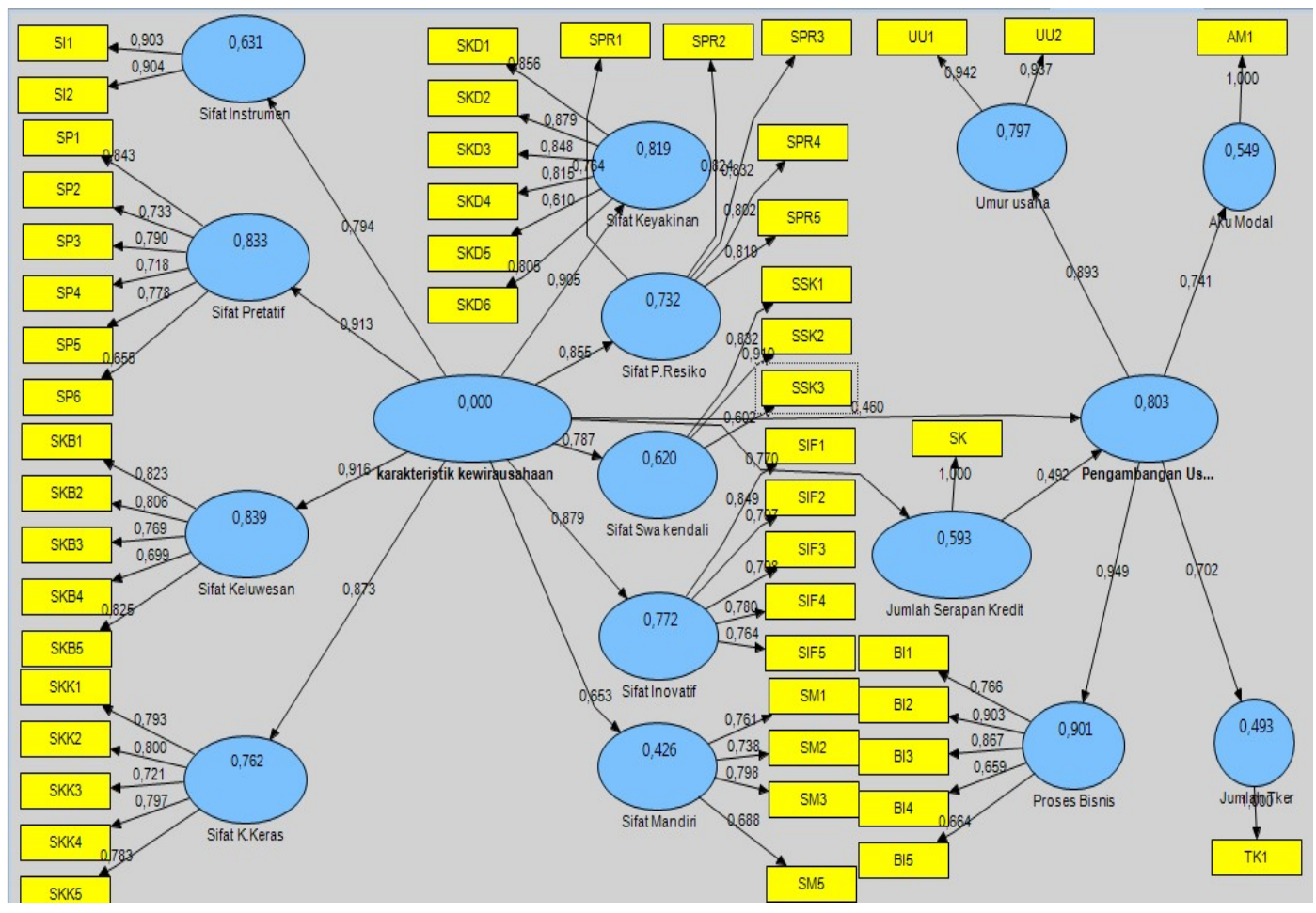

Figure 1. Measurement and Structural Model Results

From the analysis results obtained the value of the square root of the Average Variance Extracted (AVE) on the business process variable is 0.7784 , can be seen in Table 2. The value is higher than the correlation value between business processes and other variables that is 0.7484 . The square root value of AVE is higher than the correlation value between different variables, 
meaning that all latent variables in this study have good discriminant validity. Based on a holistic evaluation of the results of convergent validity, discriminant validity, and composite reliability, it can be concluded that the indicator as a measurement of latent variables is a valid and reliable measurement.

Table 2. Average Variance Extraction (AVE) Value

\begin{tabular}{lccc}
\hline & AVE & Square root AVE & $\begin{array}{c}\text { Correlation } \\
\text { Maximum Value }\end{array}$ \\
\hline Business Process & 0.605935 & 0.778418268 & 0.748443 \\
Innovative & 0.582681 & 0.763335444 & 0.722627 \\
Instrumental & 0.815994 & 0.903323862 & 0.709005 \\
Hard-work & 0.607413 & 0.779367051 & 0.645811 \\
Sociable & 0.617195 & 0.785617591 & 0.684352 \\
Confidence & 0.651586 & 0.807208771 & 0.646001 \\
Independent & 0.558525 & 0.747345302 & 0.371200 \\
Calculated Risk Taker & 0.654039 & 0.808726777 & 0.702032 \\
Pretative & 0.570412 & 0.755256248 & 0.723242 \\
Self-control & 0.627264 & 0.792000000 & 0.542325 \\
Business age & 0.882843 & 0.939597254 & 0.722627 \\
\hline
\end{tabular}

\subsection{Structural Model}

From the $\mathrm{R}$ square test results obtained that the greater the value of $\mathrm{R}$-square, the more significant the ability of exogenous variables can be explained by endogenous variables so that the structural equation is better.

Table 3. R-square Value

\begin{tabular}{ll}
\hline & R Square \\
\hline $\begin{array}{l}\text { Entrepreneurship characteristic } \rightarrow \text { Credit absorption } \\
\begin{array}{l}\text { Entrepreneurship characteristic } \rightarrow \text { Credit absorption } \rightarrow \text { Business } \\
\text { development }\end{array}\end{array}$ & 0.593379 \\
\hline
\end{tabular}

Based on the R-square value above, it states that the business performance variable is influenced by the entrepreneurial characteristics variable and access to credit by $80.32 \%$. Access to credit can is influenced by the characteristic entrepreneurial variable of $59.33 \%$. Q-square value is in the amount of 0.9198 . Q-square value $>0$ shows that model has predictive relevance. Q-square has a value between $0<\mathrm{Q} 2<1$, we're closer to 1 means that the model is better.

\subsection{Impact of Entrepreneurship Characteristics on Business Performance}

From the results of the analysis in Table 4 shows the T-value in the amount of 7.23 whose value is higher than T-table 1.645 at $95 \%$ confidence intervals and alpha levels of $5 \%$ and $99 \mathrm{df}$. It can 
be concluded that the entrepreneurial characteristics positively influence the performance of the sugar processing business brown. The average sample value of 0.463751 shows that entrepreneurial characteristics have a positive and significant relationship to business performance, where $46.37 \%$ increase in entrepreneurial characteristics contribute to improving business performance. The results show that there is more than $60 \%$ of other factors that affect business performance.

Table 4. Result for Inner Weight of Entrepreneurship Characteristic Variable Role Toward Business Development

\begin{tabular}{lcccc}
\hline & $\begin{array}{c}\text { Original } \\
\text { Sample }(\mathrm{O})\end{array}$ & $\begin{array}{c}\text { Sample } \\
\text { Mean (M) }\end{array}$ & $\begin{array}{c}\text { Standard } \\
\text { deviation } \\
(\text { STDEV })\end{array}$ & $\begin{array}{c}\text { T Statistics } \\
(|\mathrm{O} / \mathrm{STERR}|)\end{array}$ \\
\hline $\begin{array}{l}\text { Entrepreneurship characteristic } \\
\rightarrow \text { Business development }\end{array}$ & 0.460095 & 0.463751 & 0.063631 & 7.230703 \\
\hline
\end{tabular}

Business development requires all stakeholders such as internal business support, and government support to provide entrepreneurship education, guidance and counseling, and capital assistance. Government support will increase the intention of companies to improve their business performance. The intention of entrepreneurs to improve business performance is determined by their understanding of entrepreneurship, socio-economic factors, community culture, and business opportunities.

Character of business actors and the character of small businesses influence the success of small businesses [10]. A person's character and motivation have a positive impact on business performance [11].

\subsection{Impacts Entrepreneurship Characteristic to Access to Credit}

The results of the analysis in Table 5 shows that the T-value in the amount of 21.48 is higher than t-table 1.645 at the $95 \%$ confidence interval and the alpha level of $5 \%$ and df 99 . It can be concluded that entrepreneurial characteristics have a positive effect on the performance of the colored sugar processing business chocolate. The average sample value of 0.772035 , so that the characteristics of entrepreneurship have a positive and significant impact, where an increase of $77.20 \%$ entrepreneurial characteristics contribute to increasing access to credit.

Table 5. Result for Inner Weight Credit Absorption Amount towards Business Development

\begin{tabular}{lcccc}
\hline & $\begin{array}{c}\text { Original } \\
\text { Sample (O) }\end{array}$ & $\begin{array}{c}\text { Sample } \\
\text { Mean (M) }\end{array}$ & $\begin{array}{c}\text { Standard } \\
\text { deviation } \\
(\text { STDEV })\end{array}$ & $\begin{array}{c}\text { T Statistics } \\
(|\mathrm{O} / \mathrm{STERR}|)\end{array}$ \\
\hline $\begin{array}{l}\text { Entrepreneurship } \\
\text { characteristic } \rightarrow \text { credit } \\
\text { absorption }\end{array}$ & 0.770311 & 0.772035 & 0.035848 & 21.488493 \\
\hline
\end{tabular}

Based on the test results, it can be concluded that the entrepreneurial characteristics strongly influence the amount of credit received by business actors. Entrepreneurial characteristics influence decision making and risk-taking. Therefore, entrepreneurial characteristics are the 
determining factors that affect credit access. Entrepreneurial characteristics will change managerial practices, which will ultimately affect business performance. Access loan from banking or non-banking financial institutions must be supported by the charm of entrepreneurial abilities, innovative abilities, and business management to make small business competitive [12]. Business actors who have entrepreneurial characteristics will manage their business optimally and try to develop their business by utilizing credit as business capital assistance [13].

\subsection{Impacts Access to Credit on Business performance}

The results of the analysis in Table 6 show that the T-value in the amount of 7.32 is higher than T-table 1.645 at a $95 \%$ confidence interval and an alpha level of $5 \%$, and df 99 so that it can be concluded that access to credit has a positive effect on the brown sugar processing business. The average sample value is 0.487339 , meaning $48.73 \%$ of the amount of access to credit contributes to influencing business performance.

Table 6. Result for Inner Weight Credit Absorption Amount towards Business Development

\begin{tabular}{lcccc}
\hline & $\begin{array}{c}\text { Original } \\
\text { Sample (O) }\end{array}$ & $\begin{array}{c}\text { Sample } \\
\text { Mean (M) }\end{array}$ & $\begin{array}{c}\text { Standard } \\
\text { deviation } \\
(\text { STDEV) }\end{array}$ & $\begin{array}{c}\text { T Statistics } \\
(\mid \mathrm{O} / \text { STERR })\end{array}$ \\
\hline $\begin{array}{l}\text { Credit abseoption amount } \rightarrow \\
\text { Business development }\end{array}$ & 0.492471 & 0.487339 & 0.066966 & 7.354035 \\
\hline
\end{tabular}

Access to credit by entrepreneurs can be useful in improving business operations, managing finances, as well as managerial aspects. Capital can improve business management, which results in improved business performance [14]. The higher the capital used, the easier access to credit for business development [15].

Based on empirical studies, it can be concluded that access to credit will increase the accumulation of venture capital so that it can increase the use of factors of production and better use of technology. Credit can be used to purchase sugar cane presses, repair equipment, increase labor, and raw materials. Increasing business activity will improve business performance.

Table 7. Calculation of Direct Effect, Indirect Effect, and Total Effect

\begin{tabular}{cccc}
\hline \multirow{2}{*}{$\begin{array}{c}\text { Between Variables } \\
\text { Effect }\end{array}$} & Direct & Indirect (Through) & \multirow{2}{*}{ Total } \\
\cline { 2 - 3 } & & SK & 0.8399 \\
KK - PU & 0.4637 & $0.4873^{*} 0.7720=0.3762$ & 0.7720 \\
KK - SK & 0.7720 & - & 0.4673 \\
SK - PU & 0.4673 & - & \\
\hline
\end{tabular}

The analysis results in Table 7 show that entrepreneurs' characteristics affect business performance directly and indirectly through credit absorption of $83.99 \%$. Improved business performance can be achieved if business people have the characteristics of entrepreneurs and can access credit. Credit in the form of capital can be used by businesses to improve their business performance. 
[16] states that efforts to develop small businesses can begin with improving production equipment, increasing efficiency and productivity through work systems that aim to improve production processes; continued improvement in the quality of human resources through education and training; after that, the availability of raw materials and is easier; availability of capital that can be accessed by a simple procedure; increasing small business competitiveness and business managerial ability.

\section{Conclusion and Recommendation}

\subsection{Conclusion}

Based on the results of research and discussion, it can be concluded that:

1. The characteristics of brown sugar processing entrepreneurs in the Agam District can be categorized at a moderate level. Entrepreneurial characteristics affect business performance directly and indirectly through the access to credit.

2. Entrepreneurial characteristics directly affect credit access. Credit accessed by brown sugar entrepreneurs from Agribusiness Microfinance Institutions (LKM-A) and others from banks.

3. Access to credit directly affects business performance

\subsection{Recommendation}

The recommendations of this study are:

1. Improving business performance requires government support through training, mentoring, consulting, and facilitating the creation of business networks.

2. Brown sugar business performers need to improve their entrepreneurial character to improve business performance and courage to access credit.

3. The availability of credit that can be accessed with more comfortable procedures.

\section{REFERENCES}

[1] T. S. Hatten, Small Business Management: Entrepreneurship and Beyond. Cengage Learning, 2012.

[2] P. Harsono, "Analisis bantuan kredit terhadap perkembangan kelompok usaha bersama," Jurnal Ekonomi dan Kebijakan, vol. 5, no. 2, pp. 148-158, (2012).

[3] A. A. R. Aditya and H. K. S. Daryanto, "Pengaruh modernitas sikap kewirausahaan terhadap keberhasilan umkm tempe dan tahu di Kabupaten Bogor," Forum Agribisnis, vol. 5, no. 1, pp. 25-45, 2017.

[4] V. A. Yanti, S. Amanah, and P. Muldjono, and P. Asngari, "Faktor yang mempengaruhi keberlanjutan usaha mikro kecil menengah di Bandung dan Bogor," Jurnal Pengkajian dan Pengembangan Teknologi Pertanian, vol. 20, no.2, pp. 137148, Juli 2018.

[5] P. W. Tresna and S. J. Raharja, "Effect of entrepreneurial orientation, product innovation and competitive advantage on business performance in creative 
industries in Bandung City, Indonesia," Review of Integrative Business and Economics Research, vol. 8, no. 3, pp. 51-60, 2019.

[6] F. Hanifati and H. D. Waluyo, "Pengaruh harga, brand image,dan kualitas pelayanan terhadap keputusan pembelian (Studi kasus gracia skin clinic Semarang)," Diponegoro Journal of Social and Politic, pp. 1-7, 2018, [Online]. Available: http://ejournal- s1.undip.ac.id/index.php/1-7.

[7] M. A. Islam, M. A. Khan, A. Z. M. Obaidullah, and M. S. Alam, "Effect of entrepreneur and firm characteristics on the business success of small and medium enterprises (SMEs) in Bangladesh," International Journal of Business and Management, vol. 6, no. 3, pp. 289-299, 2011.

[8] Abdulwahab, M. H., \& Al-damen, R. A. (2015). The Impact of Entrepreneurs ' Characteristics on Small Business Success at Medical Instruments Supplies Organizations in Jordan Amman Arab University Business Administration Department Amman Arab University. International Journal of Business and Social Science, 6(8), 164-175Abdulwahab, M. H., Al-damen, R. A. (2015).

[9] Sugiyono, Metode Penelitian Kombinasi (Mixed Methods). Bandung: Alfabeta, 2015

[10 K. Bhatt and P. Sankhla, "A study on impact of entrepreneurial characteristics on success of business," International Journal of Trend in Scientific Research and Development, vol. 2, no. 5, pp. 1112-1115., 2018.

[11]R. Ahmad, "Moderating effect of motivation in the relationship of intellectual capital and business performance : an evidence on Pakistan textile sector," Journal of Studies in Social Sciences and Humanities, vol. 5, no. 1, pp. 12-26, 2019.

[12] S. Lestari, Perkembangan dan Strategi Pengembangan Pembiayaan Usaha Mikro Kecil dan Menengah (UMKM). Bidang Pengkajian Sumberdaya UMKM, 2010.

[13]L. Kozubíková, J. Dvorský, M. Cepel, and A. P. Balcerzak, "Important characteristics of an entrepreneur in relation to risk taking: Czech Republic case study," Journal of International Studies, vol. 10, no. 3, pp. 220-233, 2017.

[14]K. Putri, A. Pradhanawati, and B. Prabawani, "Pengaruh karakteristik kewirausahaan, modal usaha dan peran business development service terhadap pengembangan usaha (studi pada sentra industri kerupuk Desa Kedungrejo Sidoarjo Jawa Timur)," Jurnal Ilmu Administrasi Bisnis, vol. 3, no. 4, pp. 313-322, 2014.

[15]E. Purwanti, "Pengaruh karakteristik wirausaha, modal usaha, strategi pemasaran terhadap perkembangan UMKM di Desa Dayaan dan Kalilondo Salatiga," Among Makarti, vol. 15, no. 9, pp. 13-28, 2012.

[16] M. Kuncoro, Ekonomika Pembangunan: Masalah, Kebijakan, dan Politik. Jakarta: Erlangga, 2010. 